\title{
Influence of Personality Traits and Age on Academic Self-Handicapping among Undergraduate Students of Ahmadu Bello University, Zaria, Nigeria
}

\author{
Anna Litvinova, Musa Balarabe, Aisha I. Mohammed \\ Department of Educational Psychology and Counselling, Ahmadu Bello University, Zaria, Nigeria \\ Email:anyabello@yahoo.com
}

Received 29 October 2015; accepted 4 December 2015; published 7 December 2015

Copyright (C) 2015 by authors and Scientific Research Publishing Inc.

This work is licensed under the Creative Commons Attribution International License (CC BY).

http://creativecommons.org/licenses/by/4.0/

(c) (i) Open Access

\begin{abstract}
The present study examined the differences in academic self-handicapping among undergraduate students based on personality traits and age. Participants $(N=440)$ completed two questionnairesBig Five Inventory and Self-handicapping Scale. Analysis of data reveals that significant negative correlation exists between academic self-handicapping of undergraduates and their next personality traits-agreeableness, conscientiousness and openness to new experience (with $r=-.322$, -.317 and -.161 respectively), while with neuroticism this correlation is positive $(r=.439)$. The academic self-handicapping did not show any significant correlation with extraversion and students' age. Considering the negative impact of academic self-handicapping in educational process and significant relationship between academic self-handicapping and personality traits, teachers and counsellors need to pay more attention to students' personality as one of the important factors affecting motivation and achievement.
\end{abstract}

\section{Keywords}

Personality Traits, Academic Self-Handicapping, Age, Undergraduates, Nigeria

\section{Introduction}

Almost every research conducted in area of education in Nigeria indicates that students' academic achievement at all levels of educational system has become a problem (Popoola \& Olarewaju, 2010; Akinsanya \& Omotayo, 2013). It is noted that despite the numerous factors contributing to students low achievement, such as declining 
qualification and commitment of teachers; inadequate provision of facilities; outdated curricula, low social value of education, difficult economic situation (Duze, 2011), the students themselves contribute to their own failure by using self-handicapping strategies. Although, self-handicapping is general self-protective strategy, academic self-handicapping is a common problem particularly significant for students in tertiary system, including Ahmadu Bello University. Students use self-handicapping strategies for protecting their self-esteem, but consequences of this behaviour such as performance decrease, negative emotions and problems with adjustment make these strategies not self-protective, but self-delusional. To be able to provide useful and helpful recommendation for students and teachers at the end, the role of personality traits (extraversion, neuroticism, conscientiousness, agreeableness and openness to new experience) and students' age in self-handicapping behaviour will be in focus of this research.

\subsection{Academic Self-Handicapping}

Self-handicapping is a widespread strategies that can be found in variety of cultures and professional areas. It can be observed in any area where people are expected to perform - in the business, sport, daily life and especially in academic environment. Academic settings provide a lot of situations where students display their abilities and performance in the presence of others (teachers and peers) and this achievement situations make some of them worry and concerned with how others will judge them in case of potential failure. This made them to be involved in self-handicapping behaviour and start looking for excuses before actual performance, by creating real or verbal impediments.

The term of Self-handicapping was introduced by Steven Berglas and Edward E. Jones in 1978. Jones and Berglas (1978) conceptualized self-handicapping as a self-protective strategy that is used for protecting internal characteristics of individual such as self-esteem. Self-handicapping is the type of behaviour that helps individuals to reduce responsibility for failure in their own eyes, as well as in the eyes of the public (Jones \& Berglas, 1978). People actively use this strategy to arrange circumstances or their behaviour in the way that if failure will occur, the reason will be seen in these circumstances rather than in luck of ability, people prefer to be seen as victims of circumstances, but not as unable or incompetent (Midgley \& Urdan, 1995). The aim of self-handicappers is to maintain positive feelings about themselves at the cost of dealing effectively with the situation (Zuckerman et al., 1998). Strube (1986) define self-handicapping as "strategic attempts to create performance settings that will channel post performance attributions in a self-serving manner". The basic principles for self-handicapping, according to Jones and Berglas (1978), are principles of discounting and augmentation, formulated by Kelly. In case of failure self-handicappers will discount an attribution for poor performance to lack of ability and attribute it to the obstacles. In the event of success ability will be augmented because the selfhandicapper succeeds despite the impediments (Rhodewalt \& Hill, 1995).

The nature of self-handicapping is paradoxical—from one side individuals have desire to avoid failure and trying to protect their self or public esteem, but at the same time they create impediments that make this failure more possible. This contradiction between motives and behavior of self-handicappers has been explained by Elliot and Church (2003) in their work on motivational analysis of self-handicapping. They divided failure into two types-specific failure on task in a given situation and global failure as a person or his ability or intellect. Self-handicappers have desire to avoid global failure and they create obstacles that can make specific failure more likely, but these obstacles (excuses) eliminate the possibility of global failure.

Self-handicapping has two important features-it occurs before activity and it is intentional. First and foremost, self-handicapping is proactive or anticipatory strategy, that occurs before an event. The individuals here start looking for explanation and rationalization for possible failure and create obstacles before the activity. If the self-handicapping person does poorly, he or she will have a ready excuse for it and will blame obstacles for this failure. If the person does well, he can say that he or she overcame the impediment. This proactive nature distinguishes self-handicapping from causal attribution, when explanations are made after the performance. According to Urdan and Midgley (2001), self-handicapping is a prior strategy, not just post-factum excuse.

Secondly, self-handicapping is intentional and self-regulatory behaviour for coping with expected poor performance (Urdan \& Midgley, 2001). If a student didn't prepare for exam because he has forgotten about it—it is not self-handicapping, but if he intentionally didn't read before exam and already has excuses for this—it is self-handicapping.

Individuals differ in the extent to which they self-handicapped, research have found a number of personality 
traits and characteristics that have been related to self-handicapping. Kinon and Murray (2007) in their own study on a profile of college self-handicappers found that self-handicapping was negatively related to openness to new experiences, conscientiousness, agreeableness, autonomy, positive relations with others, self-acceptance, personal growth, optimism, college self-efficacy, generalized self-efficacy, and satisfaction with life, while selfhandicapping was positively related to neuroticism. The positive correlation was also found between self-handicapping and external locus of control (Acka, 2012), depression, anxiety and stress (Sahranc, 2011), perfectionism (Pulford, Johnson, \& Awaida, 2005).

Some researchers proposed that self-handicapping can protect or enhance an individual's self-worth and selfesteem. Hirt and McCrea (2009) suggested that self-handicapping effectively maintain positive self-esteem and positive beliefs about their own ability. However, majority of research proposed that self-handicapping has negative long-time consequences. Zuckerman et al. (1998) conducted a longitudinal research to examine the influence of self-handicapping strategies on coping, academic performance and adjustment. They found that high level of self-handicapping is strongly associated with low academic performance, poor adjustment and negative self-focus. People with high score of self-handicapping used more dysfunctional, emotion-focused coping strategies, such as self-blame, behavioural and mental disengagement. Students, who were highly engage in selfhandicapping, reported worst study habits, such as shorter and less efficient exam preparations, that lead to lower GPA. High self-handicapping was positively related with low self-esteem, but as mentioned earlier, these two constructs reinforce each other. According to Zuckerman et al. (1998), higher score in Self-handicapping Scale was also related to a higher number of visits to the university health service; this fact supports the notions of negative correlation between self-handicapping and well-being. Sahranc (2011) reported that students with high self-handicapping are more likely to have negative emotional outcomes such as depression, anxiety and stress.

Some of self-handicapping strategies, such as using drugs or alcohol can create a serious social and health problems. Self-handicapping, especially behavioural, has negative interpersonal consequences, Hirt, McCrea and Boris (2003) reported that others evaluate self-handicappers as irresponsible, lazy and will not like to work with them on future tasks. All these facts provide evidence that the practice of self-handicapping puts the person at risk (Zuckerman et al., 1998).

\subsection{Personality Traits}

Different psychological schools have different understanding of personality and its structure, based on their theoretical approaches. The trait approach in study of personality emphasizes importance of different dimensions or variables of personality. For trait theorists-Allport, Cattell, Eyzenck, personality consists of relatively stable and consistent characteristics (traits) that are unique for each individual. Traits are mental set or readiness of individuals to respond to different variety of situations in a consistent and stable way. According to trait theories, personality can be described by person's unique profile, made from different positions of each of the traits dimensions.

Trait approach in describing and understanding personality has a long and rich history. Ancient Creek and Roman philosophers were trying to describe personality and organize it into types. Greek physician Hippocrates and later Roman physician Galen proposed four personality types, viz., sanguine (cheerful, enthusiastic), melancholic (sad, depressive), choleric (angry, hostile) and phlegmatic (stolid, apathetic) that are corresponding with four kind of fluids (called humors) in human body (blood, black bile, yellow bile, and phlegm) (Boeree, 2006).

Gordon Allport, one of the first trait theorists, proposed that personality can be described by the combination of traits. Allport divided all personality traits into three major categories: cardinal, central and secondary. Cardinal traits are the traits that some people have (not all, relatively few people developed these traits) and which practically define their life. Central traits are a prominent traits of personality and secondary traits - these are traits that exhibited in some situations. Raymond Cattell is a trait theorist who divided traits into surface and source traits. Surface traits- these are traits that can be recognized by behaviour, while source traits—are the source that determine behaviour. Hans Eysenck offered the other model of trait structure of personality. He described personality by two, later expanded to three basic traits: neuroticism, extraversion and psychoticism. These major aspects of personality, according to Eysenck, are largely genetically determined and can be explained by differences in functions of autonomic nervous system.

Analyzing all previous research findings and list of possible traits of personality, researchers concluded that 
some traits are repeated from study to study. Despite the various traits name, they were similar factors. Psychologists reached the agreement that personality can be described by these fundamental traits. These include five basic traits—openness to experience, neuroticism, extraversion, agreeableness and conscientiousness. These five dimensions of personality (often called Big Five) gave basis for Five Factor Model, theory that describes and explains personality in terms of Big Five traits. The Big Five, was introduced in 1963 by Warren Norman, in 1990 R. R. McCrae and P. T. Costa, Jr., presented their version, called The Five Factor Theory (Boeree, 2006).

Traits, according to the Five Factor Theory (FFT), are stable structures of personality that are not changing with time and circumstances (Costa \& McCrea, 2006). According to FFT, traits must be distinguished from other personality attributes such as attitudes, habits, beliefs, values. All these attributes (Characteristic Adaptations) can and do changed over the time or circumstances, while personality traits (Basic Tendencies) stay relatively stable throughout the life. Basic Tendencies, or basic personality traits, shape the development of Characteristic Adaptations and it is important to know individual's trait profile for understanding and predicting his or her behaviour (Costa \& McCrea, 2006).

The five major personality dimensions can be described as these (Huffman, 2004; John \& Gosling, 2009):

- Openness to experience vs. Closed mindedness

(original, imaginative, curious, open to new ideas) vs. (uncreative, uncurious, conventional)

- Conscientiousness vs. Lack of direction

(responsible, self-disciplined, organized and achieving) vs. (irresponsible, careless, impulsive, lazy, disorganized)

- Extraversion vs. Introversion

(sociable, outgoing, talkative, active) vs. (quite, passive, reserved, inhibited and withdrawn)

- Agreeableness vs. Antagonism

(good-natured, warm, cooperative, helpful, trusting) vs. (irritable, argumentative, ruthless, suspicious and uncooperative)

- Neuroticism-Emotional stability

(emotionally unstable, prone to anxiety, guild, worry and moodiness) vs. (emotionally stable, calm, easygoing and relaxed)

According to Brislin and Lo (2006), people with each of the five construct can be described as follow:

1) Openness to experience

People with this trait are usually creative, aesthetic sensitive, have high level of imagination and wide range of interests. They are curious, demonstrate a need for variety and new unfamiliar experiences and highly introspective.

\section{2) Conscientiousness}

People, who scored high in this dimension, are self-disciplined, responsible, organized and have higher need for achievement and greater persistence. They exhibit highly ethical behaviour.

\section{3) Extraversion}

People are more sociable, because social behaviour is satisfying their need for reward. They are more impulsive, spontaneous, talkative, energetic and enthusiastic, like excitement and experience positive emotions more often. Extraverts are more oriented to external social world, rather than internal private world (like introverts).

\section{4) Agreeableness}

Individuals with this personality trait tend to demonstrate sympathy, emotional support, altruism and cooperation with others and seek for harmony. They are trusting and tolerant people, who easily liked by others.

\section{5) Neuroticism}

This construct describes people who are more likely to experience mood fluctuations, negative emotions and negative affects, such as anxiety, anger, depression, guild, disgust and hostility. They are not always able to control impulses and cope with stress (Davis \& Palladino, 1996).

Personality traits and their influence on the individuals' behaviour and motivation in the achievement situations, especially in educational settings are the well researched area in psychology. A great number of studies were conducted on relationship between personality characteristics and strategies that individuals used in process of learning - causal attribution, coping, learning and self-protective strategies, among them self-handicapping.

Ross, Canada and Rausch (2002) investigated relationship between self-handicapping and five basic personal- 
ity traits measured by Five Factor Model—neuroticism, extraversion, openness to experience, agreeableness and conscientiousness. They measured self-handicapping (Self-handicapping Scale) and five personality traits (NEO Personality Inventory) of undergraduate students and found the correlation between these variables. Each trait was measure by six subscales (facet), i.e. subscale Openness to experience has Fantasy, Aesthetics, Feelings, Actions, Ideas and Values Facets. Self-handicapping was positively related to Neuroticism and negatively related to Conscientiousness. All facets of Neuroticism (Anxiety, Angry hostility, Depression, Self-consciousness, Impulsiveness and Vulnerability) were correlated with self-handicapping, most significant positive correlation was with Depression facet. While in Conscientiousness domain (Competence, Order, Dutifulness, Achievementstriving, Self-discipline and Deliberation) most significant negative correlation was with Self-discipline. Other traits (extraversion, openness and agreeableness) did not show significant correlation with self-handicapping, only some selective facets such as Fantasy facet in Openness was positively related and in Agreeableness facet of Trust was negatively correlated with self-handicapping. The authors suggested that Neuroticism and Conscientiousness play the dominant role in predicting self-handicapping.

The other research that tried to establish what is the correlation between personality traits and self-handicapping behaviour was conducted by Kinon, M. and Murray, C. in University of California, USA in 2007. They tried to clarify the profile of the average college self-handicapper. Together with other psychological characteristics such as psychological well-being, optimism, sell-efficacy, self-esteem, satisfaction with life and presence of meaning in life, researchers measured the five basic personality traits (by using the Big Five Inventory). The results of this study showed that self-handicapping was negatively related to openness to new experiences, conscientiousness, agreeableness and positively related to neuroticism. From the results of their own study Kinon and Murray (2007) found that the average college self-handicapper tends to have lower self-esteem, self-efficacy and satisfaction with life, to be less open to new experiences, less agreeable, also tends to fear negative evaluation and have higher neuroticism and lover conscientiousness.

Nosenko, Arshava and Nosenko (2014) in the research of self-handicapping as a coping strategy, that was conducted in Dnipropetrovsk National University, Ukraine, suggested that personality factors are fundamental in understanding self-handicapping as a coping strategy. Along with Proactive Strategy Inventory, Rosenberg Self-esteem Scale, General Self-Efficacy Scale, Self-Handicapping Scale, they used NEO Five Factor Inventory for measuring Big Five personality traits. From the results of the study they reported that the high level of neuroticism, uncertainty in self-efficacy and low level of subjective well-being were predictors of self-handicapping behaviour as non-constructive proactive coping. The findings of this research give evidence that personality traits are fundamental in understanding coping ability and in predicting self-handicapping as specific proactive coping style.

\section{Method}

\subsection{Participants}

Respondents ( $\mathrm{N}=$ 440, 319 male, 121 female) were drawn from four faculties of Ahmadu Bello University, Zaria, Nigeria to represent (conditionally for the purpose of this study) the four main directions of study in the University (Arts, Humanitarian science, Technical science and Science). Students were divided into three age groups, the majority of students-275 were age between 20 - 25 years, 94 respondents were age less than 20 and 71 students were more than 26 years.

\subsection{Instruments}

\subsubsection{Big Five Inventory (BFI)}

This 44 item inventory was developed by John, Donahue, and Kentle (1991) to assess personality from positions of five basic traits (Big Five): Extraversion (8 items), Agreeableness (9 items), Conscientiousness (9 items), Neuroticism (8 items) and Openness to experience (10 items). It is 5 point Likert scale, consists of Agree strongly (AS), Agree a little (A), Neither agree nor disagree (NS), Disagree a little (D), and Disagree strongly (DS). Each degree of agreement has numerical score (from 1 to 5) and the total score will be computed by summing up scores from all statements.

John et al. (1991) reported high reliability with Cronbach alpha coefficient .80 and clear factor structure of BFI. This inventory, according to Nwoke and Chukwuorji (2011), was adapted for the use of professionals in 
Nigeria and has good reliability and validity coefficient for Nigerian sample.

\subsubsection{Self-Handicapping Scale (SHS)}

The SHS was developed by Jones and Rhodewalt in 1982. It is a 25 -item self-report measure that uses a 6 point Likert format scale for answers from 0 (disagree very much) to 5 (agree very much). This scale has been used in many studies, predominantly in an academic environment, for measuring the individual tendency to use selfhandicapping strategies. The SHS contains 2 subscales for behavioural-items 2, 3, 5, 6, 11, 13, 20, 22 (e.g., "I tend to put things to the last moment") and claimed-items 1, 4, 8, 9, 15, 16, 18, 19, 21, 23, 25 (e.g., "Sometimes I get so depressed that even easy tasks become difficult") self-handicapping. This scale is summative scale, with items 3, 5, 6, 10, 13, 20, 22 and 23 being reversed scored.

The researcher made some adaptation of this scale by changing some words with more simple and suitable for environment. The original 6 point Likert scale was replace with 5 point scale (from 0 to 4 ). SHS (original version) has good internal consistency—alpha coefficient $r=.78$ and 1-month test-retest reliability $r=.74$ (Strube, 1986). The pilot study was carried out with the purpose of establishing internal and 3 weeks test-retest reliability of BFI and SHS after adaptation of these instruments to Nigeria settings. Internal consistency coefficient for 25 items of SHS was establish as .521. After deleting items 3, 10, 14, 24 that give negative item-total correlation, internal consistency of scale was improved to .649. The total number of items after adaptation became 21, with items $4,5,11,17,19,20$ being reversed. The minimum possible total score -0 and maximum possible total score-84. Three-week test-retest reliability coefficient with number of cases 50 was establish as .832 .

\subsection{Procedure}

The instruments (Personal Information Inventory, Big Five Inventory and Self-handicapping Scale) were administered to the students in each selected department from the four faculties. Before to administration of instruments all participants were instructed and told about purpose of the study. Students were instructed that there is no right or wrong answers and they must just select answer that is most closely describes their personality or typical behaviour. Completion of the inventories was with the guarantee of confidentiality.

\subsection{Statistical Analysis}

For analyzing data researcher used program IBM SPSS Statistics Version 20. Appropriate statistical techniques were used for analyzing data for establishing relationship between variables. The Pearson Product Moment Correlation (PPMC) coefficient was used to test the relationship between students' personality traits and academic self-handicapping. One-way Analysis of Variance (ANOVA) was employed to find differences in academic self-handicapping among students from different age groups.

\section{Results}

The outcome of Pearson Product Moment Correlation statistics (Table 1) shows that there is no significant relationship between academic self-handicapping and extraversion. The calculated $\mathrm{p}$ value of .572 is greater than the 0.01 level of significance. Significant correlation exists between academic self-handicapping and other four personality traits-agreeableness, conscientiousness, neuroticism and openness to new experience. This is because the calculated p values $(.000, .000, .000$ and .001 for each trait respectively) are less than 0.01 level of significance used in this analysis. Analysis shows that strong negative correlation exists between academic selfhandicapping and agreeableness, academic self-handicapping and conscientiousness with calculated correlation index $r=-.322$ and $r=-.317$ respectively, while calculated correlation index for openness is negative too $(r=-.161)$. Results of PPMC analysis indicated strong positive correlation between academic self-handicapping and neuroticism with $\mathrm{r}=.439$.

Calculated significant value for correlation between academic self-handicapping and students' age is .054 (Table 2 and Table 3), it is indicated that there is no any significant relationship between academic self-handicapping and students age. Students from age group less than 20 demonstrated lowest level of self-handicapping (mean $=39.2340)$, follow by age group $20-25$ years (mean $=40.3709$ ); the higher level of self-handicapping $($ mean $=42.1127)$ showed by students from age group more than 26 years. 
Table 1. Results of pearson product moment correlation analyses on relationship between academic self-handicapping and personality traits (extraversion, agreeableness, conscientiousness, neuroticism and openness).

\begin{tabular}{ccccccc}
\hline & & Extraversion & Agreeableness & Conscientiousness & Neuroticism & Openness \\
\hline & Pearson & -.027 & $-.322^{*}$ & $-.317^{*}$ & $.439^{*}$ & $-.161^{*}$ \\
Academic & Correlation & .572 & .000 & .000 & .000 & .001 \\
Self-Handicapping & Sig. (2-Tailed) & .57 & 440 & 440 & 440 \\
\hline
\end{tabular}

${ }^{*}$ Correlation is significant at the 0.01 level (2-tailed).

Table 2. Descriptive statistics for academic self-handicapping by age.

\begin{tabular}{|c|c|c|c|c|c|c|c|c|}
\hline \multirow{2}{*}{ Age } & \multirow{2}{*}{$\mathrm{N}$} & \multirow{2}{*}{ Mean } & \multirow{2}{*}{ Std. Deviation } & \multirow{2}{*}{ Std. Error } & \multicolumn{2}{|c|}{ 95\% Confidence Interval for Mean } & \multirow{2}{*}{ Minimum } & \multirow{2}{*}{ Maximum } \\
\hline & & & & & Lower Bound & Upper Bound & & \\
\hline$<20$ & 94 & 39.2340 & 7.05040 & .72719 & 37.7900 & 40.6781 & 17.00 & 59.00 \\
\hline $20-25$ & 275 & 40.3709 & 7.67263 & .46268 & 39.4601 & 41.2818 & 14.00 & 58.00 \\
\hline$>26$ & 71 & 42.1127 & 7.74145 & .91874 & 40.2803 & 43.9450 & 18.00 & 61.00 \\
\hline Total & 440 & 40.4091 & 7.58916 & .36180 & 39.6980 & 41.1202 & 14.00 & 61.00 \\
\hline
\end{tabular}

Table 3. Results of one-way ANOVA statistic of academic self-handicapping and students’ age.

\begin{tabular}{ccccc} 
& Sum of Squares & Df & Mean Square & F \\
Between Groups & 336.247 & 2 & 168.123 & 2.945 \\
Within Groups & $24,948.117$ & 437 & 57.090 \\
Total & $25,284.364$ & 439 & & .054 \\
\hline
\end{tabular}

\section{Discussion}

The findings of this research indicated that majority of personality traits (agreeableness, conscientiousness, neuroticism and openness) have significant correlation with academic self-handicapping. There is strong positive correlation between academic self-handicapping and students' neuroticism. Higher level of anxiety, emotional instability, feeling of tense, vulnerability, impulsiveness are in strong positive relationship with uses of selfhandicapping strategies. This result is in agreement with the reports by Ross et al. (2002), who found strong positive correlation between self-handicapping and neuroticism. Similarly, Nosenko et al. (2014) in their research on self-handicapping as a coping strategies reported that individuals with high level of neuroticism have high level of self-handicapping. Kinon and Murray (2007) in their profile of college self-handicapper also found that self-handicapping was positively related to neuroticism.

On the other hand strong negative correlation exists between academic self-handicapping and agreeableness, conscientiousness, openness to new experience. These findings are also in agreement with results of other researchers. Ross et al. (2002) in their research found strong negative correlation with conscientiousness.

In the research carried out in Iran by Rastegar et al. (2012) investigating personality traits, achievement goals and educational self-handicapping among university students, the negative indirect influence of openness to experiences and agreeableness on educational self-handicapping through achievement goals was also reported. Similarly Kinon and Murray (2007) by using Big Five Inventory revealed negative correlation of self-handicapping and openness, agreeableness and conscientiousness.

These results suggested that personality traits are a very important factor in phenomenon of self-handicapping and can be seen as strong predictors of uses unproductive coping strategies as academic self-handicapping.

\section{Conclusion}

Some student personality traits affect level of academic self-handicapping. High level of the student neuroticism leads to higher use of academic self-handicapping strategies. On the other hand, high levels of agreeableness, 
conscientiousness and openness to new experience make students reduce the use of self-handicapping strategies. According to findings of this study, extraversion does not affect the level of self-handicapping of students. Also students' age does not correlate with level of academic self-handicapping.

The following recommendations are given on the basis of findings of this research.

1) Considering the significant relationship between academic self-handicapping and personality traits, teachers need to pay more attention to students' personalities as one of the important factors affecting motivation and achievement.

2) Counsellors should give counselling to students with high level of neuroticism, considering the fact that these students are in higher risk for choosing unproductive coping strategies, including self-handicapping.

3) Parents, teachers, psychologists and counsellors should teach students, especially with high tendency for self-handicapping, to emphasize more on their personal efforts than just expectation of sheer luck.

\section{References}

Acka, F. (2012). An Investigation into the Self-Handicapping Behaviours of Undergraduates in Terms of academic Procrastination, the Locus of control and Academic Success. Journal of Education and Learning, 1, 288-297.

Akinsanya, O. A., \& Omotayo, K. F. (2013). Falling Standard of Engineering Education in Nigeria Causes and Suggestions. International Journal of Advancements in Research \& Technology, 2, 93-96.

Boeree, C. G. (2006). Personality Theories: Hans Eysenck and Others. http://www.ship.edu/\%7Ecgboeree/perscontents.html

Brislin, R. W., \& Lo, K. D. (2006). Culture, Personality, and People’s Uses of Time: Key Interrelationships. In M. Hersen, \& J. C. Thomas (Eds.), Comprehensive Handbook of Personality and Psychopathology, Vol. 1. (pp. 44-64). Hoboken: Wiley \& Sons, Inc.

Costa, P. T., \& McCrae, R. R. (2006) Trait and Factor Theories. In M. Hersen, \& J. C. Thomas (Eds.), Comprehensive Handbook of Personality and Psychopathology. Vol. 1. (pp. 96-115). Hoboken: Wiley \& Sons, Inc.

Davis, S. F., \& Palladino, J. J. (1996). Psychology. 2nd Edition. Upper Saddle River, NJ: Prentice Hall,

Duze, C. O. (2011) Falling Standard in Nigeria Education: Traceable to Proper Skills-Acquisition in Schools? Educational Research, 2, 803-808.

Elliot, A. J., \& Church, M. A. (2003). A Motivational Analysis of Defensive Pessimism and Self-Handicapping. Journal of Personality, 71, 369-396. http://dx.doi.org/10.1111/1467-6494.7103005

Hirt, E. R., \& McCrea, S. M. (2009). Man Smart, Woman Smarter? Getting to the Root of Gender Differences in Self-Handicapping. Social and Personality Psychology Compass, 3, 260-274. http://dx.doi.org/10.1111/j.1751-9004.2009.00176.x

Hirt, E. R., McCrea, S. M., \& Boris, H. (2003). “I Know You Self-Handicapped Last Exam”: Gender Differences in Reaction to Self-Handicapping. Journal of Personality and Social Psychology, 1, 177-193. http://dx.doi.org/10.1037/0022-3514.84.1.177

Huffman, K. (2004). Psychology in Action (7th ed.). Hoboken, NJ: John Wiley \& Sons, Inc.

John, O. P., \& Gosling, S. D. (2009). Personality Traits. In A. E. Kazdin (Ed.), Encyclopedia of Psychology (pp. 140-144). Oxford: Oxford University Press.

John, O. P., Donahue, E. M., \& Kentle, R. L. (1991). The Big-Five Inventory-Version 4a and 54. Berkeley, CA: Berkeley Institute of Personality and Social Research, University of California.

Jones, E. E., \& Berglas, S. (1978). Control of Attributions about the Self through Self-Handicapping Strategies: The Appeal of Alcohol and the Role of under Achievement. Personality and Social Psychology Bulletin, 4, 200-206. http://dx.doi.org/10.1177/014616727800400205

Kinon, M., \& Murray, C. (2007). A Profile of the College Self-Handicapper. University of California, Riverside: Undergraduate Research Journal, 1, 13-17. http://ugrj.ucr.edu/journal/volume1/MarcKinon.pdf

Midgley, C., \& Urdan, T. (1995). Predictors of Middle School Students' Use of Self-Handicapping Strategies. Journal of Early Adolescence, 15, 389-411. http://dx.doi.org/10.1177/0272431695015004001

Nosenko, D., Arshava, I., \& Nosenko, E. (2014). Self-Handicapping as a Coping Strategy: Approaches to Conceptualization. Advance in Social Sciences Research Journal, 1, 157-166. http://dx.doi.org/10.14738/assrj.13.205

Nwoke, M. B., \& Chukwuorji, J. B. (2011). Social Change and Personality Development in a Nigerian Sample. International Journal of Psychological Studies, 3, 164-170. http://dx.doi.org/10.5539/ijps.v3n2p164

Popoola, F. R., \& Olarewaju, R. R. (2010). Factors Responsible for Poor Performance of Students in Mathematics in Nigeria Secondary Schools. Journal of Research in Education and Society, 1, 55-65.

Pulford, B. D., Johnson, A., \& Awaida, M. (2005). A Cross-Cultural Study of Predictors of Self-Handicapping in University 
Students. Personality and Individual Differences, 39, 727-737. http://dx.doi.org/10.1016/j.paid.2005.02.008

Rastegar, A., Afshari, M., Seif, M. H., \& Jahromi, R. G. (2012). Investigating the Intermediate Role of Achievement Goals among Personality Traits and Educational Self-Handicapping among Payam-E-Noor University Students. Journal of American Science, 8, 353-356.

Rhodewalt, F., \& Hill, K. (1995). Self-Handicapping in the Classroom: The Effects of Claimed Self-Handicaps on Responses to Academic Failure. Basic and Applied Social Psychology, 16, 397-416. http://dx.doi.org/10.1207/s15324834basp1604_1

Ross, S. R., Canada, K. E., \& Rausch, M. K. (2002). Self-Handicapping and the Five Factor Model of Personality: Mediation between Neuroticism and Conscientiousness. Personality and Individual Differences, 32, 1173-1184. http://dx.doi.org/10.1016/S0191-8869(01)00079-4

Sahranc, U. (2011). An Investigation of the Relationships between Self-Handicapping and Depression, Anxiety, and Stress. International Online Journal of Educational Sciences, 3, 526-540.

Strube, M. J. (1986). An Analysis of the Self-Handicapping Scale. Basic and Applied Psychology, 7, 211-224. http://dx.doi.org/10.1207/s15324834basp0703_4

Urdan, T., \& Midgley, C. (2001). Academic Self-Handicapping: What We Now, What More There Is to Learn. Educational Psychology Review, 13, 115-138. http://dx.doi.org/10.1023/A:1009061303214

Zuckerman, M., Kieffer, S. C., \& Knee, C. R. (1998). Consequences of Self-Handicapping: Effects on Coping, Academic Performance and Adjustment. Journal of Personality and Social Psychology, 74, 1619-1628.

http://dx.doi.org/10.1037/0022-3514.74.6.1619 